\title{
Development of prototype solar-biomass hybrid dryer and its performance evaluation using salted fish (Cynoglossus spp.)
}

\author{
K. ELAVARASAN, VINITHA VERMA AND B. A. SHAMASUNDAR \\ College of Fisheries, Mangalore, Karnataka Veterinary, Animal and Fisheries Sciences University, Mangalore - 575002 \\ Karnataka, India \\ e-mail: bashamasundar@rediffmail.com
}

\begin{abstract}
Salted and dried fishes are the source of low cost dietary protein. Solar drying is an alternative method to traditional open sun drying to produce high quality product and minimise the post-harvest losses. The solar-biomass hybrid dryer (in which solar energy and heat energy from biomass burning are integrated) is gaining momentum. In the present study, a solar-biomass hybrid dryer (SBHD) was fabricated using polycarbonate sheet as solar collector which has advantages of longer durability over glass and polythene sheets. Coconut husk with shell was used as the source of biomass. Salted soles (Cynoglossus spp.) were used to evaluate the drying efficiency. Temperature and relative humidity recorded in the dryer during the experiment were in the range of 35 to $50^{\circ} \mathrm{C}$ and 24 to $40 \%$, respectively. The drying rate curve of salted soles dried in SBHD did not show constant rate drying period. Drying efficiency of solar energy and biomass energy in the designed dryer was 10.66 and $34.66 \%$ respectively. The overall drying efficiency of the SBHD was 18.33. Mathematical modeling of the data on drying indicated that the Page model describes satisfactorily the drying characteristics of salted soles in SBHD.
\end{abstract}

Keywords: Coconut husk, Drying efficiency, Fish drying, Mathematical modeling, Salted soles, Solar-biomass hybrid dryer

\section{Introduction}

Salted and dried fish are an important source of low cost dietary protein (Bellagha et al., 2007). Fish drying is common in the coastal areas of India. Dried fishes have demand both in domestic as well as international market and play an important role in employment generation. About $7 \%$ of total export of seafood from India is contributed by dried fish items (MPEDA, 2013). Drying is mainly carried out by traditional open sun drying method and has limitations in relation to control over the drying process like weather uncertainties, requirement of large drying area and more drying time, insect infestation, mixing with dust and other foreign materials and contamination of the product due to human and animal activities (Fudholi et al., 2010). Solar drying is an alternative to the traditional sun drying for producing products of required quality and for minimising the post-harvest losses (Reza et al., 2005).

The structures made for the deliberate use of solar energy to heat air and /or the products so as to achieve drying of the products is termed as solar dryer and the process is solar drying, which is more efficient and hygienic. As the product is enclosed in the dryer, it is protected from dust, insects, birds, rodents and animals (Sharma et al., 2009). Solar dryer has the limitation that it can be used only during daytime and the drying process has to be continued next day which leads to inferior product and limits production (Madhlopa and Ngwalo, 2007). To get better quality product, it is necessary to provide solar dryer with any form of back-up heating. These limitations led to the development of hybrid dryer wherein, the solar energy and biomass energy are made use to dry the food item. The concept of integrating the solar dryer with biomass drying has gained momentum as the product can be dried continuously without loss in quality (Kumar and Bhattacharya, 2005).

The objective of the present work was to evaluate the performance of solar-biomass hybrid dryer (SBHD) designed, fabricated and installed at College of Fisheries, Mangalore, in which polycarbonate sheet was used as solar panel and coconut husk with shell as biomass. A field level experiment was carried out with soles (Cynoglossus spp.). The salted soles were dried in the SBHD and four mathematical models were used to evaluate the drying data.

\section{Materials and methods}

Fish

Fresh soles (Cynoglossus spp.) were purchased from fish landing center in Mangalore, India and transported to the laboratory in polystyrene boxes with crushed ice within $30 \mathrm{~min}$ of purchase. They were washed with potable water and salted using dry salting technique. Fishes were arranged in alternative layers with salt. The salt to fish ratio was 1:2 
(w/w). The salting was carried out in polystyrene boxes at room temperature $\left(27 \pm 2^{\circ} \mathrm{C}\right)$ for $23 \mathrm{~h}$. After salting, the fish were rinsed briefly before the drying experiments.

\section{Solar-biomass hybrid dryer (SBHD)}

The solar-biomass hybrid dryer was fabricated in the College of Fisheries, Mangalore and comprised three different parts viz., solar collector, drying chamber and biomass heat exchange system (Fig. 1).

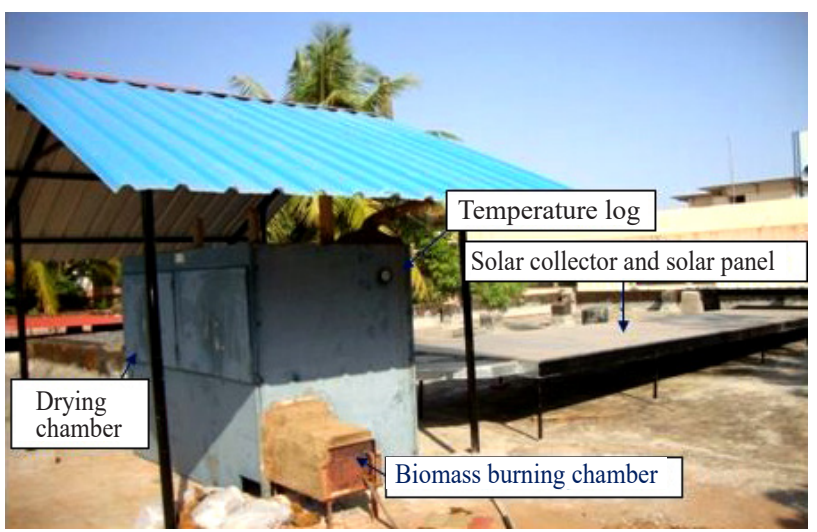

Fig. 1. The solar-biomass hybrid dryer installed at College of Fisheries, Mangalore

\section{Drying of salted soles in solar-biomass hybrid dryer}

Salted soles weighing about $58 \mathrm{~kg}$ were arranged in trays of the dryer in a single layer. The drying operation was started at about $1130 \mathrm{hrs}$ on the day of the experiment. Drying of soles using solar energy was done up to $1530 \mathrm{hrs}$ (4 h). Then the burning of biomass (coconut husk) was initiated and continued up to $2130 \mathrm{hrs}$. The biomass was fed in to the burning chamber periodically in such a way as to keep the temperature fluctuation in the drying chamber minimum. The soles were left in the drying chamber till next day morning up to $0930 \mathrm{hrs}$.

\section{Drying related parameters}

The temperature and relative humidity in the drying chamber were recorded using inbuilt temperature sensor and hygrometer, respectively. The solar radiation incident was recorded using Pyranometer. The weight of the biomass fed to the burning chamber was recorded to calculate the energy input from biomass. The changes in the moisture content of soles were also determined during drying period.

\section{Moisture content}

Samples were drawn randomly from drying chamber at different time intervals, chopped and ground using household mixing grinder. Samples of known weight were dried in the hot air oven at $105 \pm 2^{\circ} \mathrm{C}$ for $12-16 \mathrm{~h}$. The weight difference was used to calculate the moisture content and expressed in $\mathrm{kg}$ of moisture per $\mathrm{kg}$ of solid.

Drying rate

Drying rate was calculated using the following formula (Akpinar et al., 2006):

$$
\text { Dryingrate }\left(D_{R}\right)=\frac{M_{t+d t}-M_{t}}{d t}
$$

where, $\mathrm{M}_{\mathrm{t}+\mathrm{dt}}$ are moisture content at $\mathrm{t}+\mathrm{dt}$ ( $\mathrm{kg}$ water per $\mathrm{kg}$ dry matter), $\mathrm{M}_{\mathrm{t}}$ is moisture content at time $\mathrm{t}$ (drying time) and $\mathrm{t}$ is the drying time

\section{Drying efficiency of solar-biomass hybrid dryer}

Drying efficiency of the solar-biomass hybrid dryer was estimated as ratio of energy utilised for the evaporation of total amount of water to the sum of solar energy input to the collector and total heat input by the biomass (during biomass operation) as given in the following formula:

Drying efficiency $(\%)=\frac{\text { Amount of energy utilised for evapoartion of water }}{\text { Total energy input tos ystem }} \times 100$

\section{Mathematical modeling of drying kinetics of soles}

Four mathematical models were used in order to predict the moisture ratio at given drying period. The mathematical models tested are given in Table 1 along with the equation followed. The models include Page, Wang and Singh, Henderson and Pabis and Asymptotic regression (Chavan et al., 2008).

Table 1. Mathematical models used to evaluate the drying data

\begin{tabular}{ll}
\hline Model name & Model equation \\
\hline Page & $\mathrm{M}_{\mathrm{R}}=\exp \left(-\mathrm{kt}^{\mathrm{n}}\right)$ \\
Wang and Singh & $\mathrm{M}_{\mathrm{R}}=1+\mathrm{at}+\mathrm{bt}^{2}$ \\
Henderson and Pabis & $\mathrm{M}_{\mathrm{R}}=\mathrm{a} \exp (-\mathrm{kt})$ \\
Asymptotic regression & $\mathrm{M}_{\mathrm{R}}=\mathrm{a}_{0}+\mathrm{a} \exp (-\mathrm{kt})$ \\
\hline
\end{tabular}

where, $M_{R}$ - moisture ratio (dimensionless), $a, a_{0}, b$ - empirical drying model parameter, $\mathrm{n}$ - constant, $\mathrm{k}$ - empirical coefficient in the drying models $\left(\mathrm{h}^{-1}\right)$, $\mathrm{t}$ - drying time

The moisture ratio was calculated using the following formula (Yaldiz et al., 2001):

$$
\text { Moisture ratio }\left(\mathrm{M}_{\mathrm{R}}\right)=\frac{\text { Moisture at time } \mathrm{T}}{\text { Initial mositure content }}
$$

\section{Statistical analysis}

The experimental moisture ratio was fitted to the four mathematical models using Microsoft Office Excel 2007. The best fit for drying models was given by the highest coefficient of determination $\left(\mathrm{R}^{2}\right)$ and the lowest values of root mean square error (RMSE) and chi square $\left(\chi^{2}\right)$ (Akpinar, 2006). The statistical parameters were calculated as follows: 


$$
\begin{aligned}
& \chi^{2}=\sum_{i=1}^{N} \frac{(M R \text { exp, } i-M R \text { pre, } i)^{2}}{N-n} \\
& \text { RMSE }=\left[\frac{1}{N} \sum_{i=1}^{N}\left(M_{\text {exp }, i}-M R_{\text {pre }, i}\right)^{2}\right]
\end{aligned}
$$

where, $\mathrm{MR}_{\text {exp } \mathrm{i}}=\mathrm{i}^{\text {th }}$ experimentally observed moisture ratio, $\mathrm{MR}_{\mathrm{pre}, \mathrm{i}}=\mathrm{i}^{\text {th }}$ predicted observed moisture ratio, $\mathrm{N}=$ Number of observations, $\mathrm{n}=$ Number of constants in the model.

\section{Results and discussion}

\section{Solar-biomass hybrid dryer}

The schematic diagram and photograph of solar collector designed and fabricated using polycarbonate sheet is given in Fig. 2. A solar collector with the dimension of $28.70 \times 6.88$ feet (length $\times$ width) was fabricated with polycarbonate sheet. The inclination of solar collector was fixed at $5^{0}$ to capture maximum solar radiation. From the solar collector, hot air was driven into the drying chamber with 3 electric fans provided at the extreme end of solar collector. The entry of hot air from solar collector to drying

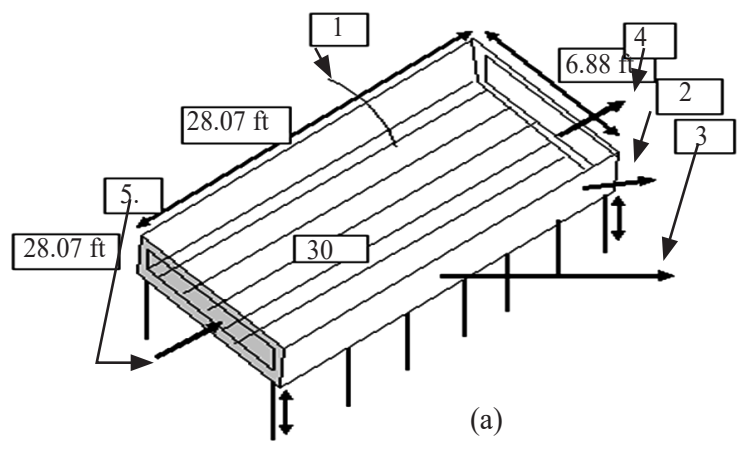

Fig. 2. (a) Schematic diagram, (b) Photograph of solar collector.

(1) Black corrugated iron sheet on the base, (2) Metal body made up of 24 guage GI sheets, (3) Bayer MWs to be affixed along these top edges of the collector, (4) Air outlet, (5) Air inlets for drying chamber)

chamber was made at four points so as to achieve uniform distribution of heat in the drying chamber. The photograph of the front view of drying chamber is given in Fig. 3. The drying chamber consists of a double-walled cuboid box, made of galvanised iron (24 gauges) on both sides with the provision to arrange the trays in zigzag manner for better air circulation. The pathway for the solar radiation heated air to the drying chamber is given in Fig. 4. The drying chamber comprised an area of 126 feet $^{2}$ with the provision to dry approximately $100 \mathrm{~kg}$ of wet fish. Biomass heat exchange system was integrated with the drying chamber and the flue gas path way and biomass burning chamber is presented in Fig. 5A-B. It consists of a long spiraling duct within the drying chamber in which the high temperature flue gases from the burnt biomass travels through the ducts along the drying chamber dissipating heat to the air so as to achieve drying. The flue gases never come in contact with fish during drying. The biomass used for burning was coconut husk.

\section{Performance evaluation of solar-biomass hybrid dryer temperature, relative humidity and solar radiation}

The data on temperature and relative humidity of the drying chamber during drying of salted soles is given in Fig. 6a. Temperature during solar drying was nearly constant for first $4 \mathrm{~h}$ and when the drying mode was switched over to biomass there was slight decrease in temperature and increase in relative humidity. Total time for drying in biomass mode was nearly $18 \mathrm{~h}$. Temperature and relative humidity greatly influence the drying pattern of food products in any drying system. Drying rate of the product is controlled by the relative humidity. Lower the relative humidity, greater is the absorbance capacity of drying air (Chavan et al., 2008). Average solar radiation of the day was $804 \mathrm{kw} \mathrm{m}^{-2}$. Solar radiation increased towards the middle of the day and decreased towards the end (Fig. 6b).

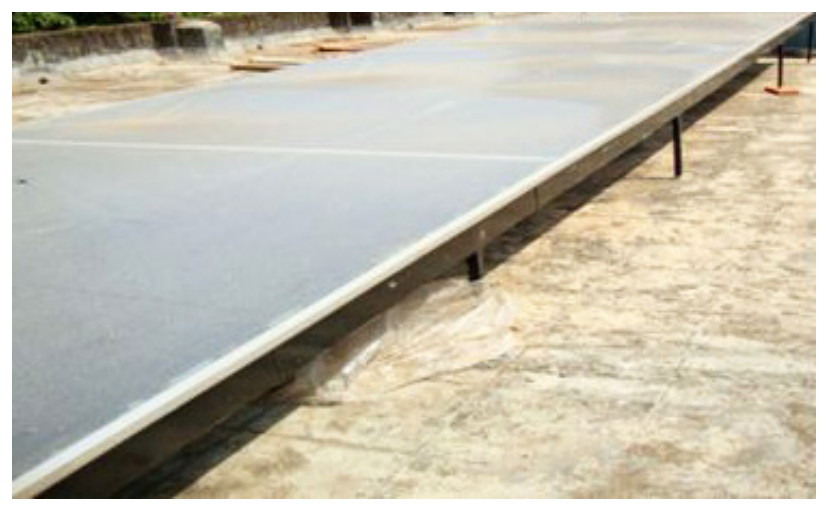

(b)

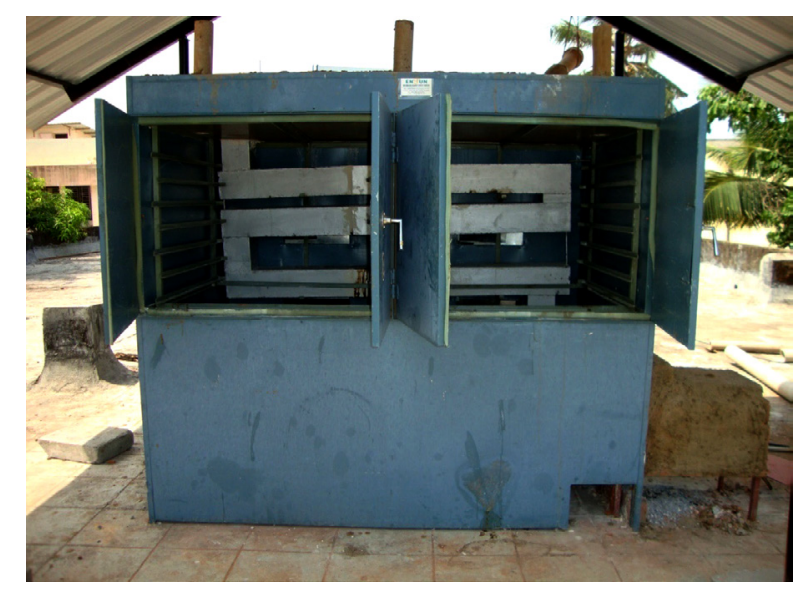

Fig. 3. Front view of the drying chamber 


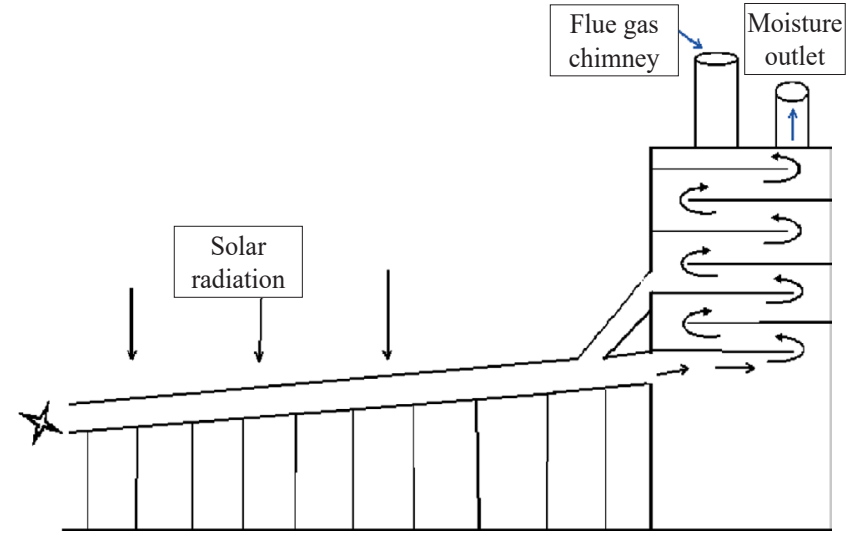

(a)

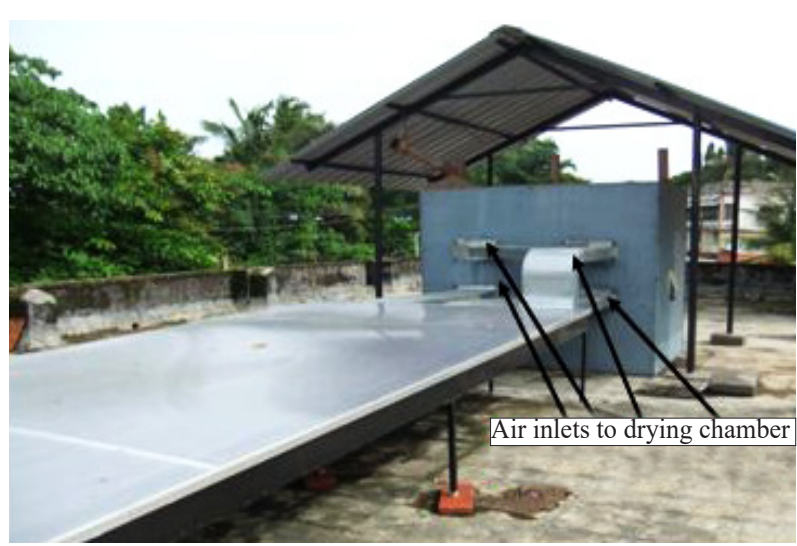

(b)

Fig. 4. (a) Schematic diagram and (b) photograph of the path way of solar radiation heated air to the drying chamber

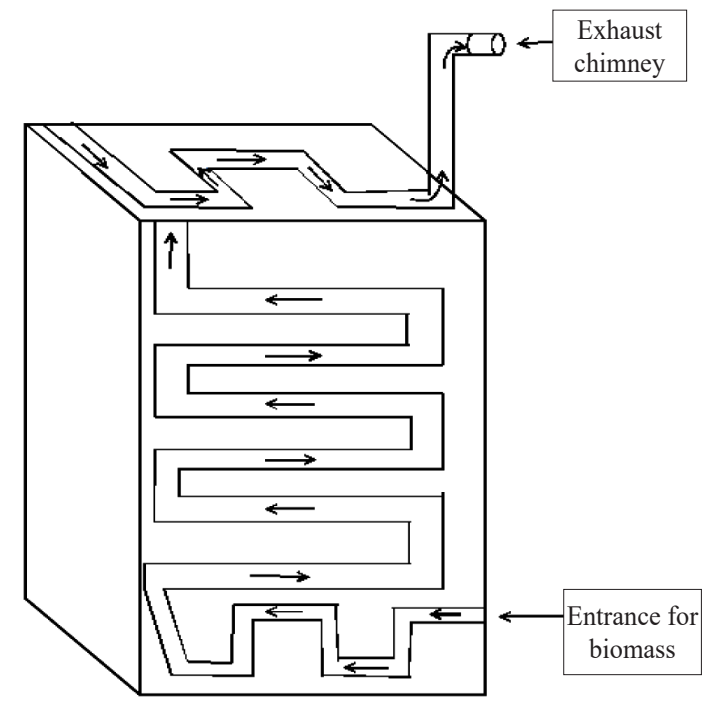

Flue gas pathway (in three different planes)

(a)

Fig. 5. (a) Flue gas pathway and (b) biomass burning chamber

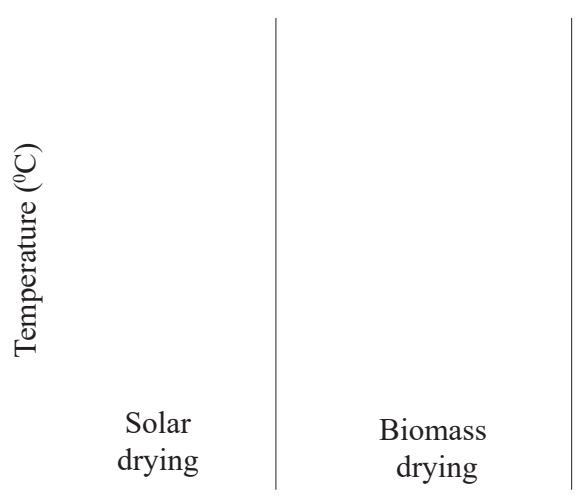

Drying period (h)

(a)

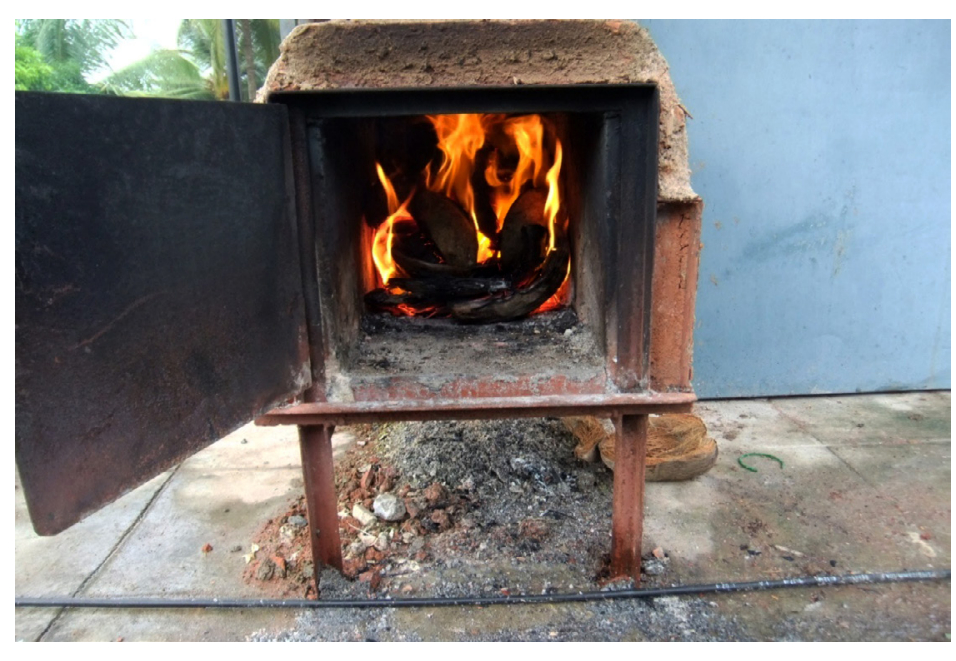

(b)

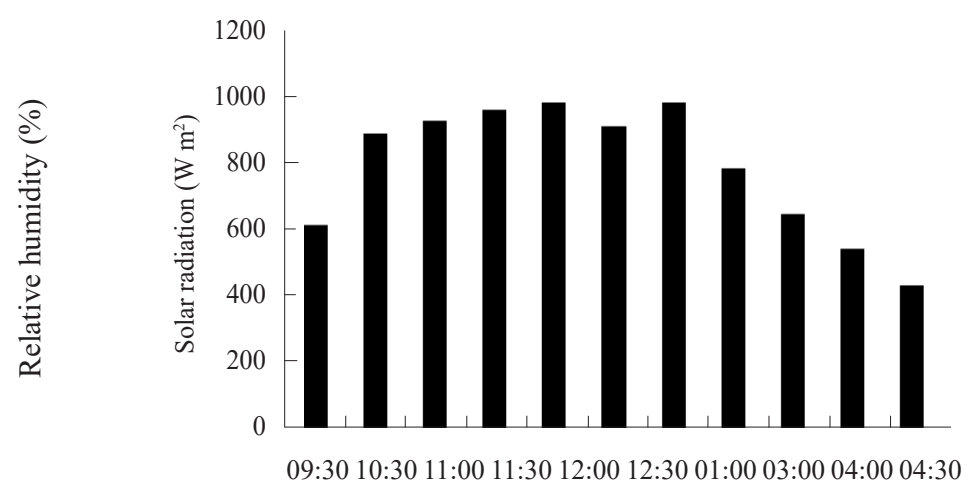

Time of day

(b)

Fig. 6. (a) Temperature and relative humidity in solar-biomass hybrid dryer during drying of salted soles. The biomass burning started after $4 \mathrm{~h}$ of solar drying and (b) solar radiation data measured by Pyranometer 


\section{Changes in the moisture content}

Changes in the moisture content of salted soles during drying in the solar-biomass hybrid dryer are given in Fig. 7(a). The initial moisture content of salted soles was $57.43 \%$ which reduced to a final moisture content of $9.60 \%$ within $23 \mathrm{~h}$ of drying. Chavan et al. (2008) reported a reduction in the moisture content of salted Indian mackerel from 71.60 to $16.09 \%$ within $27 \mathrm{~h}$ of drying time in solar tunnel dryer. In the present investigation, heat energy liberated by burning the biomass was used in combination with solar energy. It is essential to achieve lower moisture content in the end product in order to extend the shelf life of dried fish products for a considerable time.

Drying rate

Plot of drying rate versus drying period is given in Fig. 7(b). Drying rate decreased with increase in drying time. However, no constant rate of drying period was observed. This can be attributed to the nature of fish meat which does not leave any free water in fish to record constant rate of drying period (Sobukola and Olatunde, 2011). Drying of soles

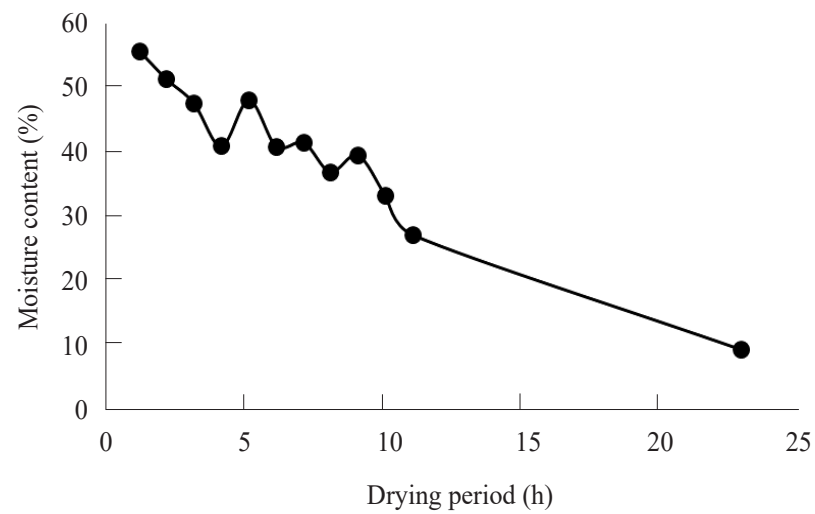

(a) efficiency of the dryer can be increased by using higher load of raw material for drying. This was further substantiated by low relative humidity of air in the drying chamber indicating that drying potential of the air was not utilised completely. Chavan et al. (2008) reported the drying efficiency of $6.30 \%$ for the solar biomass hybrid cabinet dryer during the drying experiment with Indian mackerel. Sengar et al. (2009) reported the drying efficiency of $14 \%$ for salted fish and $11 \%$ for unsalted fish dried in a solar dryer.

\section{Mathematical modeling of drying data}

Four mathematical models namely Page, Wang and Singh, Henderson and Pabis and Asymptotic regression were used to predict the moisture loss as a function of drying time. A plot of experimental and predicted moisture ratio at different drying periods is given in Fig. 8 .

The experimental and predicted values of moisture ratio were well correlated considering the coefficient of determination $\left(\mathrm{R}^{2}\right)$ (Fig. 9a-d and Table 3). Further, the values were subjected to statistical analysis so as to get the best fit model. The lower RMSE and $\chi^{2}$ values are indicative

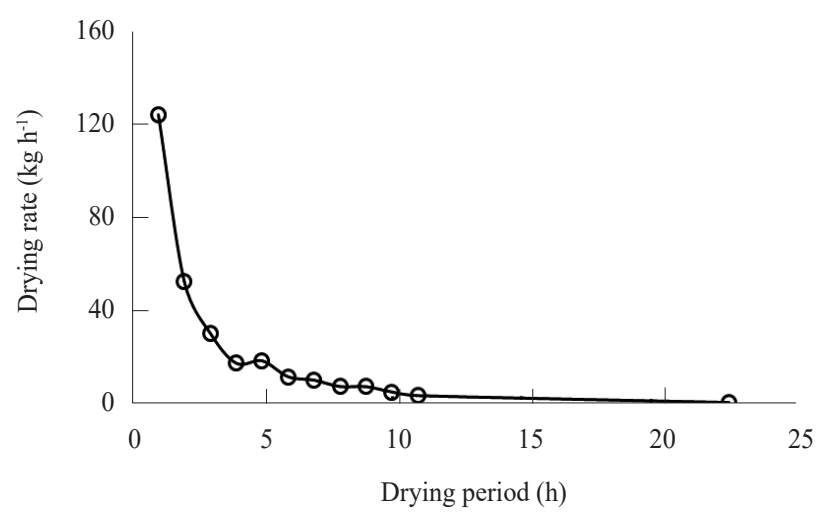

(b)

Fig. 7. (a) Changes in the moisture content and (b) drying rate of salted soles during drying in SBHD

occurred under falling rate of drying period. Internal mass transfer in the sample has been identified as the predominant mechanism during falling rate of drying period (Jain and Pathare, 2007; Sobukola and Olatunde, 2011). Similar results have been reported for drying of salted African catfish at $60^{\circ} \mathrm{C}$, salted Indian mackerel dried by solar tunnel dryer, unsalted silver jew fish dried in solar tunnel dryer and prawn and chelwa dried in open sun (Bala and Mondol, 2001; Chavan et al., 2008; Sobukola and Olatunde, 2011).

\section{Drying efficiency}

Performance of the solar-biomass hybrid dryer during drying fish is shown in Table 2. The drying efficiency of solar radiation was only $10.66 \%$. The drying efficiency of biomass was $34.66 \%$. Overall efficiency of SBHD was $18.33 \%$. The

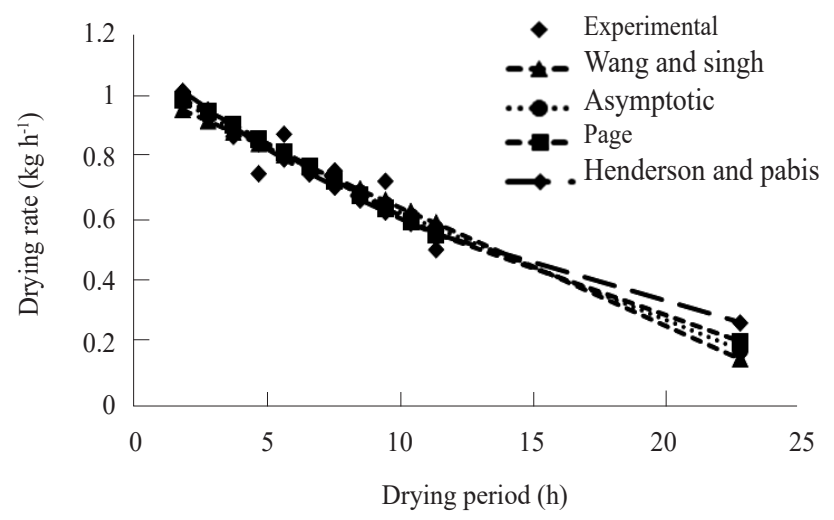

Fig. 8. Prediction of loss of moisture in salted soles during drying by Page, Wang and singh, Henderson and pabis and Asymptotic regression drying model 
Table 2. Performance characteristics of solar-biomass hybrid dryer during drying of salted soles

\begin{tabular}{llll}
\hline Parameters & Solar only & Biomass only & Hybrid \\
\hline Initial weight of salted soles (kg) & 58 & 48.22 & 58 \\
Final weight of soles (kg) & 48.22 & 33.28 & 33.28 \\
Initial moisture content of salted soles (\% w.b) & 57.43 & 40.58 & 57.43 \\
Final moisture content (\% w.b) & 40.58 & 9.6 & 9.6 \\
Water evaporated during drying (kg) & 9.78 & 14.94 & 24.72 \\
Latent heat of water evaporation (kJ kg-1) & 2272 & 2272 & 2272 \\
Energy used to evaporate water (kJ) & 22220.16 & 33943.68 & 56163.84 \\
Amount of coconut husk with shell (kg) & & $22(15.17+6.83)$ & 22 \\
Calorific value of coconut husk with shell (kJ kg-1) & & 4451 & 4451 \\
Duration of use (min) & 240 & 1140 & 1380 \\
Energy supplied by coconut husk with shell (kJ) & & 97922 & 97922 \\
Average solar radiation (W m $\left.{ }^{-2}\right)$ & 804 & & 804 \\
Collector area (m ${ }^{2}$ ) & 18 & & 18 \\
Energy from solar collector (kJ) & 208396.8 & & 208396.8 \\
Total energy supplied to the system (kJ) & & 34.66 & 306318.8 \\
Drying efficiency (\%) & 10.66 & 18.33
\end{tabular}

Energy from solar collector $=$ Area of solar collector ${ }^{*}$ Average solar radiation ${ }^{*} \min ^{*} 60=18 X 804 X 240 X 60=208396.8 \mathrm{KJ}$

Energy from biomass $=$ weight of biomass" Calorific value of biomass $=22 \times 4451=97922 \mathrm{KJ}$

Total mass of water removed $=24.72$

Energy used for water evaporation $=2272 \mathrm{X} 24.72=56163.84 \mathrm{KJ}$

Drying efficiency $=((56163) /(97922+208396.8))^{*} 100=18.33 \%$

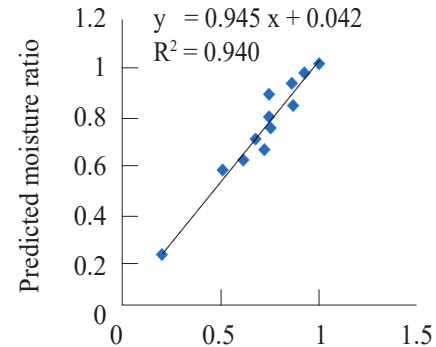

(a)

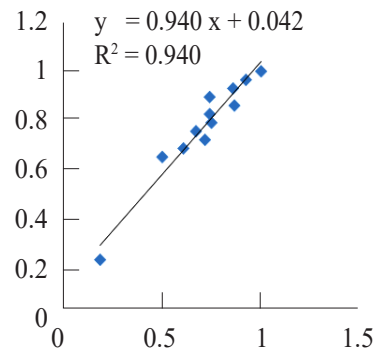

(b)

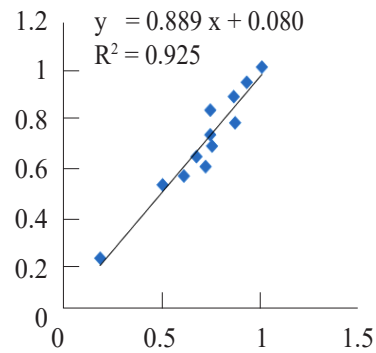

(c)

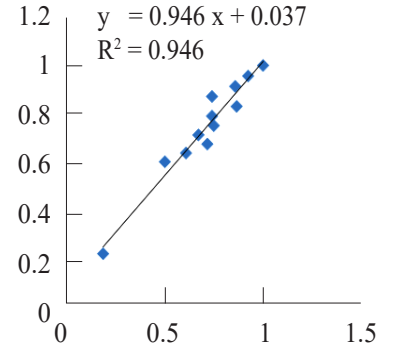

(d)

Fig. 9. Correlation between the predicted and experimental moisture ratio of mathematical model in muscle of salted soles during drying period a: Page model, b: Wang and Singh model, c: Henderson and Pabis model, d: Asymptotic regression model

Table 3. Model constants and statistical parameters like coefficient of determination $\left(\mathrm{R}^{2}\right)$, root mean square error (RMSE) and mean square of deviation $\left(\chi^{2}\right)$ values so as to get the best fit model during drying of salted soles

\begin{tabular}{|c|c|c|c|c|}
\hline Drying model & Parameters & $\left(\mathrm{R}^{2}\right)$ & $\operatorname{RMSE}\left(\times 10^{-4}\right)$ & $\chi^{2}\left(\times 10^{-4}\right)$ \\
\hline Page model & $\begin{array}{l}\mathrm{k}\left(\mathrm{h}^{-1}\right)=0.02 \\
\mathrm{n}=1.30\end{array}$ & 0.94 & 4.1 & 1.6 \\
\hline Wang and Singh & $\begin{array}{l}a=0.97 \\
b=-0.03\end{array}$ & 0.94 & 98.7 & 0.19 \\
\hline Henderson and pabis & $\begin{array}{l}\mathrm{k}\left(\mathrm{h}^{-1}\right)=0.06 \\
\mathrm{a}=1.06\end{array}$ & 0.92 & 1.5 & 0.63 \\
\hline Asymptotic regression & $\begin{array}{l}\mathrm{k}\left(\mathrm{h}^{-1}\right)=0.02 \\
\mathrm{a}=2.19 \\
\mathrm{a}_{0}=-1.18\end{array}$ & 0.94 & 13.1 & 0.005 \\
\hline
\end{tabular}

of best fit model. In the present study, the lowest RMSE value obtained for Henderson and Pabis model and the lowest $\chi^{2}$ value was obtained for Asymptotic regression. Considering the values of $\mathrm{R}^{2}$, RMSE and $\chi^{2}$ it can be said that the Page model would adequately predict the drying kinetics in solar-biomass hybrid dryer. The use of different models for 
predicting the drying kinetics varies from fish to fish and the type of drying employed (Bellagha et al., 2007; Jain and Pathare, 2007; Chavan et al., 2008; Sobukola and Olatunde, 2011). In the present investigation, the differences between the experimental and predicted values were minimal, indicating that the models used were satisfactory. The advantages of using models will help in commercial production of dried fish with desired moisture content.

The SBHD was designed and fabricated using polycarbonate sheet for solar panel which is having the advantage of more durability compared to glass or polythene sheet. The developed prototype also offers opportunity to utilise biomass such as coconut husk and this can be extended to other materials. The drying time of the fish in the solar-biomass hybrid dryer is reduced to $23 \mathrm{~h}$. The quality of the product was superior compared to conventional sun drying. Drying curve of fish in the solar-biomass hybrid dryer was in falling rate phase. The proposed mathematical models can be used to predict the moisture content or drying time to achieve the particular moisture content which will have relevance on the shelf life of the dried product. The establishment of SBHD will enable production of hygienic and safe dried fish which can fetch better returns for fisherfolk.

\section{Acknowledgements}

The financial support from European Union, Brussels under FP-7, SECUREFISH (Grant No.289282) for conducting the research work is gratefully acknowledged. The Bayer Materials Division, India is gratefully acknowledged for providing the polycarbonate sheet.

\section{References}

Akpinar, E. K. 2006. Mathematical modeling of thin layer drying process under open sun of some aromatic plants. J. Food Eng., 77(4): 864-870

Bala, B. K. and Mondol, M. R. A. 2001. Experimental investigation on solar drying of fish using solar tunnel dryer. Drying Technol., 19(2): 427-436.
Bellagha, S., Sahli, A., Farhat, A., Kechaou, N. and Glenza, A. 2007. Studies on salting and drying of sardine (Sardinella aurita): Experimental kinetics and modelling. J. Food Eng., 78(3): 947-952.

Chavan, B. R., Yakupitiyage, A. and Kumar, S. 2008. Mathematical modeling of drying characteristics of Indian mackerel (Rastrelliger kanagurta) in solar-biomass hybrid cabinet dryer. Drying Technol., 26(12): 1552-1562.

Fudholi, A., Sopian, K., Ruslan, M. H., Alghoul, M. A. and Sulaiman, M. Y. 2010. Review of solar dryers for agricultural and marine products. Renew. Sust. Energ Rev., 14(1): 1-30.

Jain, D. and Pathare, P. B. 2007. Study the drying kinetics of open sun drying of fish. J. Food Eng., 78(4): 1315-1319.

Kumar, S. and Bhattacharya, S. C. 2005. Technology packages: Solar biomass and hybrid dryers. Renewable energy technologies in Asia, A Regional research and dissemination programme. Regional Energy Resources Information Center (RERIC), Asian Institute of Technology, Thailand, p. 44-60.

Madhlopa, A. and Ngwalo, G. 2007. Solar dryer with thermal storage and biomass-backupheater. Solar Energy, 81: 449-462.

MPEDA. 2013. Marine Products Export Development Authority. www.mpeda.com. (Accessed 3 July 2015)

Reza, M. S., Bapary, M. A. J., Azimuddin, K. M., Nurullah, M. and Kamal, M. 2005. Studies on the traditional drying activities of commercially important marine fish species in Bangladesh. Pak. J. Biol. Sci., 8(9): 1303-1310.

Sengar, S. H., Khandetod, Y. P. and Mohod, A. G. 2009. Low cost solar dryer for fish. Afr. J. Environ. Sci. Technol., 3(9): 265-271.

Sharma, A., Chen, C. R. and Nguyen, V. L. 2009. Solar-energy drying systems: A review. Renew. Sust. Energ. Rev., 13(6-7): 1185-1210.

Sobukola, O. P. and Olatunde, S. O. 2011. Effect of salting techniques on salt uptake and drying kinetics of African catfish (Clarias gariepinus). Food Bioprod. Process., 89(3): 170-177.

Yaldiz, O., Ertekinn, C. and Uzun, H. I. 2001. Mathematical modeling of thin layer solar drying of Sultana grapes. Energy, 26(5): 457-465. 